\title{
Reproductive biology of Oreochromis niloticus (Perciformes: Cichlidae) at Emiliano Zapata dam, Morelos, Mexico
}

\author{
Peña-Mendoza, B., J.L. Gómez-Márquez, I.H. Salgado-Ugarte \& D. Ramírez-Noguera \\ Laboratorio de Limnología, F.E.S. Zaragoza, U.N.A.M. Av. 5 de Mayo y Fuerte de Loreto, Col. Ejército de Oriente, \\ Iztapalapa. C.P. 09230, México, D.F., Fax: 5773 6336. 1gomez@servidor.unam.mx; berthapegna@yahoo.com.mx; \\ isalgado@servidor.unam.mx
}

Received 05-I-2005. Corrected 14-VI-2005. Accepted 29-VII-2005.

\begin{abstract}
The reproductive season of tilapia was studied by monthly samplings at Emiliano Zapata dam, Morelos State, Mexico. From February 1999 through February 2000 a sample of 50 fish was taken from the commercial catch (castnet, $6.5 \mathrm{~cm}$ of mesh size). The observed sex ratio was 1:1.29 (females:males) $\left(\chi^{2}=10.26\right.$; $\mathrm{p}<0.05$ ). The tilapia reached maturity at $151.3 \mathrm{~mm}$ (females) and $152.0 \mathrm{~mm}$ (males) of total length. Rainy (August) and dry (February) seasons were determined as the breeding period. Fecundity variation was better correlated with length $(r=0.7473 ; \mathrm{p}<0.002)$ than with weight $(\mathrm{r}=0.7395 ; \mathrm{p}<0.002)$. The fecundity ranged between 243 and 847 oocytes per fish, with egg diameter from 300 to $3700 \mu \mathrm{m}$. Intensive breeding activity in August and February coincide with phytoplankton biomass increase. Rev. Biol. Trop. 53(3-4): 515-522. Epub 2005 Oct 3.
\end{abstract}

Key words: Reproduction, Oreochromis niloticus, gonadosomatic index, hepatosomatic index, fecundity.

Tilapia (Cichlidae) are native of Africa but have been introduced to other countries. Due to their economic importance, tilapias are becoming increasingly prominent in freshwater aquaculture at many regions of the world and are among the most studied groups of fish in African waters (Admassu 1996, Coward and Bromage 1998).

The Nile's tilapia Oreochromis niloticus (Linnaeus, 1757), is one of the most widespread and important species in tropical freshwater aquaculture. Actually, O. niloticus is ecologically and commercially the most important species in Mexico. The main advantage of tilapia is its relatively low cost of production, mainly for fry and feed, and the quality of its flesh. The attributes that make Nile's tilapia so suitable for fish farming, are its resistance against harsh conditions, ease of breeding, rapid growth rate, ability to efficiently convert organic and domestic wastes into high quality protein, and good taste (Yi et al. 1996, de Graaf et al. 1999).
Other advantages are its herbivorous nature and its mouth-brooding habits. In spite of these qualities, during 2001 the extensive aquaculture in Mexico only produced $77271 \mathrm{t}$ of tilapia (Anonymous 2002). This represents about $5.50 \%$ of total production from fish caught in lakes and from fish farming.

The main reason that tilapias make a relatively small contribution to fisheries production in most countries, in spite of their desirable traits, is their early sexual maturity. Tilapias reproduce when they are only a few months old, often below market weight. Early sexual maturity may also have a negative influence on growth rate (Morales 1991). A reduction in somatic growth can lead to stunted of $O$. niloticus, which is often seen as a major problem in tilapia farming. Consequently, the growth rate of adult tilapia decreases and fewer marketable-sized fish can be harvested (de Graaf et al. 1999).

Various aspects of the biology of commercially important Cichlids have been studied 
by Fryer and Iles (1972), Babiker and Ibrahim (1979), Basurto (1984), Arredondo-Figueroa and Guzmán-Arroyo (1986), Stewart (1988), Arredondo-Figueroa and Tejeda-Salinas (1989), Morales (1991), Hernández-Aviles and Peña-Mendoza (1992), Morales (1992), Gómez et al. (1993), Castrejón et al. (1995), Palacios (1995), Ramos-Cruz (1995), Admassu (1996), Gómez-Márquez (1998), de Graaf et al. (1999), Jiménez (1999), Peña and Domínguez (1999), Fawole and Arawomo (2000), Gómez et al. (2003), Jiménez and Nepita (2000), Günther and Jiménez-Montealegre (2004), AriasRodriguez et al. (2006), and Jiménez-Badillo (2006). Additionally, there are unpublished accounts on the biology of these species from Emiliano Zapata dam, Mexico. In the present study the breeding season of the fish in the dam was determined through the relationships among fecundity-length, fecundity-weight, oocyte diameter, sex ratio, gonadosomatic and hepatosomatic indexes.

\section{MATERIALS AND METHODS}

Samples from the commercial catch at Emiliano Zapata dam, located in Morelos State (18²9'57' N, 99¹6’34' W, altitude 899 m), Mexico, were taken approximately at monthly periods from February 1999 to February 2000. Fish were caught by a castnet with $6.5 \mathrm{~cm}$ of mesh size. A total of 624 fish were analyzed: 272 females and 352 males. Fish were measured for total (TL) and standard lengths (SL) to the nearest $1 \mathrm{~mm}$, weighed (total weight) to the nearest $0.1 \mathrm{~g}$ and dissected to determine sex; the gonadic maturity stage was recorded following Holden and Raitt (1975) procedures. The gonads and liver were removed and weighted to the nearest $0.01 \mathrm{~g}$. The sexual proportion male:female was obtained. The mean length at first reproduction or mean length at sexual maturity was obtained as the length at which 50 percent of all individuals are sexually mature (King 1995). Gonadosomatic index (GSI) for each fish was calculated as the weight of the gonads relative to the total body weight, expressed as a percentage (de Vlaming et al. 1982). Hepatosomatic index (HSI) was calculated for females as the weight of the liver relative to the total body weight expressed as a percentage. The monthly frequency of the various gonads stages, and mean monthly GSI and HSI were plotted by month to determine the reproductive cycle and the breeding season of the fish. Ripe female fish (188) were used for fecundity estimations. Fecundity was estimated using the total number of oocytes contained in the ovary of the fish, and diameters of the oocytes were measured with a dissecting microscope equipped with an ocular micrometer. The variation of fecundity with fish body length was estimated (Bagenal 1978). A mean fecundity from all samples was calculated using a "direct summation" procedure (Shoesmith 1990). Some environmental factors were also investigated to determinate if they are associated with the breeding cycle of the fish. Surface temperature was measured using a thermometer around 12:00 $\mathrm{hr}$ during each sampling occasion. In addition, previously measured month water temperature data for the period between 1999 and 2000 were considered. Maximum depth was measured using a dead weight. A photosynthetic pigment (chlorophyll"a") was measured by means of the Spectrophotometric method (Wetzel and Likens 1979). The catalogue number of voucher specimens is IBUNAM-P 8832

\section{RESULTS}

Sex ratio: The 624 fishes caught ranged from 141 to $255 \mathrm{~mm}$ in total length, and 40.2 to $271.4 \mathrm{~g}$ in body weight with 272 females $(43.59 \%)$ and 352 males (56.41\%). Females were more numerous from April to July and the males from October to February (Fig. 1). The sex ratio was 1:1.29 (females:males), and had high significant of the sex ratio $1: 1\left(\chi^{2}=\right.$ 10.26; $\mathrm{p}<0.05$ ).

Maturity stages: Percentage of each gonadal development stage is illustrated in 
Fig. 2 and Fig. 3. According with female's gonadic maturation stages (Fig. 2), 32.0\% of the total fishes were maturing (II), $47.0 \%$ were mature (III) and, $21.0 \%$ were ripe (IV). Therefore, $68.0 \%$ of the fish were in the reproductive process. In the males (Fig. 3) $45.0 \%$ of the total fishes were maturing (II), $51.0 \%$ were mature (III) and, $4.0 \%$ were ripe (IV). Therefore, $55.0 \%$ of the fishes were in the reproductive process.

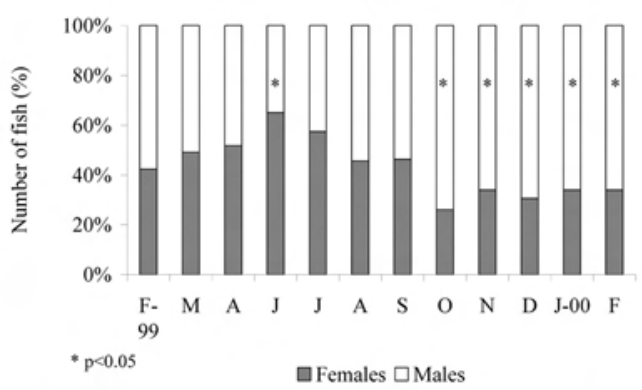

Fig. 1. Monthly sex ratio for O. niloticus.

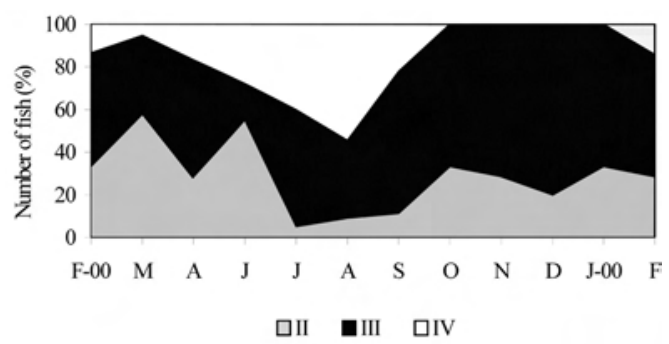

Fig. 2. Seasonal variation of maturity stages for O. niloticus ovaries.

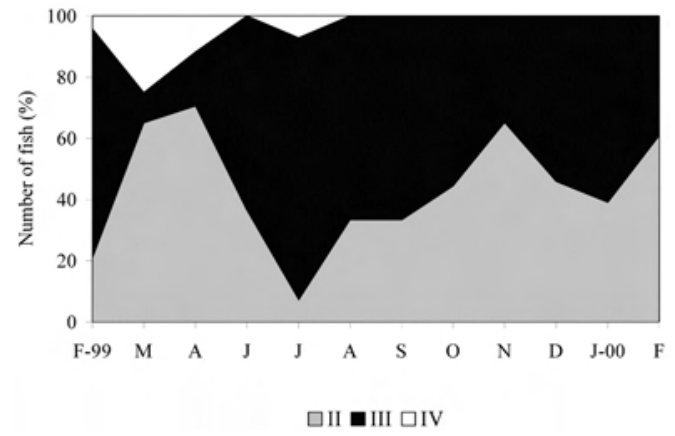

Fig. 3. Seasonal variation of maturity stages for O. niloticus testis.
The highest proportion of average gonadal ripe stage (IV) in females was found in August (Fig. 2). However, from February to September there was a reproductive season. On the other hand, the fishes in spent stage (IV) were not observed from October to January. Similar results were observed for male individuals.

Size at first maturity: The relation between body length and gonadal development was examined in 624 fishes from randomly selected catches. Young males and females attain maturity while they are in their first year of life. The smallest mature female and male observed were $140 \mathrm{~mm}$ of TL. Using logistic curve fitted values, the estimated mean lengths at sexual maturity $\left(\mathrm{L}_{\mathrm{m}}\right)$ were 151.3 and 152.0 for females and males, respectively.

Fecundity: The total lengths of 188 females examined ranged from $140 \mathrm{~mm}$ to $220 \mathrm{~mm}$, while the total weight ranged from $40.2 \mathrm{~g}$ to $185.2 \mathrm{~g}$. The absolute fecundity varied between 243 and 847 oocytes per fish and increased with increasing fish length. This relationship can be described with the curve

$$
\mathrm{F}=38.25 \mathrm{TL}^{0.8835}
$$

The correlation between fecundity and body length expressed relationship was bigger $(\mathrm{r}=0.7473, \mathrm{p}<0.05)$ than the fecundity-body weight correlation $(r=0.7395, \mathrm{p}<0.05)$. The mean fecundity obtained for tilapia through the direct summation procedure was 446 oocytes per fish.

The number of ripe oocytes increased with ovarian weight. The diameter of oocytes contained in the ovaries ranged between 300 and $1000 \mu \mathrm{m}$ for fish in gonadal stage II; between 300 and $3700 \mu \mathrm{m}$ for fish in gonadal stage III, and between 300 and $3700 \mu \mathrm{m}$ for fish in stage of gonadal stage IV (Table 1).

Testis diameter ranged between 850 and $3550 \mathrm{~m}$ by stage development II, with average length of $3.52 \mathrm{~cm}$. In the stage development III, the testis diameter ranged from 1200 to $6100 \mathrm{~m}$ with testis average length of $4.07 \mathrm{~cm}$. In the stage 
TABLE 1

Summary of gonad development stages and oocytes length in O. niloticus

\begin{tabular}{|c|c|c|c|c|c|c|}
\hline $\begin{array}{l}\text { Gonad } \\
\text { maturity } \\
\text { stage }\end{array}$ & $\begin{array}{l}\text { Gonad } \\
\text { length range } \\
(\mathrm{cm})\end{array}$ & $\begin{array}{l}\text { Gonad length } \\
\text { average } \\
(\mathrm{cm})\end{array}$ & $\begin{array}{c}\text { Oocytes } \\
\text { number } \\
\text { range }\end{array}$ & $\begin{array}{l}\text { Oocytes } \\
\text { number } \\
\text { average }\end{array}$ & $\begin{array}{c}\text { Oocytes } \\
\text { length } \\
\text { range ( } \mathrm{m})\end{array}$ & $\begin{array}{l}\text { Number } \\
\text { of } \\
\text { fish } \\
\text { analyzed }\end{array}$ \\
\hline II & $2.1-3.6$ & 2.9 & $78-1162$ & 581 & $300-1000$ & 55 \\
\hline & $2.3-4.3$ & 3.3 & $115-965$ & & $300-1000$ & \\
\hline III & & & & 481 & $\begin{array}{l}1100-2000 \\
2100-3700\end{array}$ & 60 \\
\hline IV & $3.0-4.6$ & 3.8 & $243-847$ & 435 & $\begin{array}{c}300-1000 \\
2100-3700\end{array}$ & 27 \\
\hline
\end{tabular}

development IV, the testis diameter ranged from 2150 to $6800 \mathrm{~m}$, with testis length of $6.04 \mathrm{~cm}$.

Gonadosomatic and hepatosomatic index: Monthly variation in GSI due to fish size is considered to be very small, because fish length did not vary significantly among months (ANOVA, p>0.05). However, the GSI mean values of both sexes, varied significantly among months (ANOVA, $\mathrm{p}<0.05$ ). The maximum values of the gonadosomatic index for females and males were obtained in August and February (Fig. 4). A similar pattern between gonad and liver weight means for females was detected.

Environmental factors: Data on water temperature, maximum depth and chlorophyll $a$ are presented in figure 5. During the present study, the area was characterized by two seasons: a dry season (November to May) and a rainy season (June to October). The dam water level increased in response to the"heavy rains"being high from October to January. The water temperature of the dam during this study ranged from $20.7^{\circ} \mathrm{C}$ to $27.6^{\circ} \mathrm{C}$, and was relatively high from March to October. Low temperatures were recorded from December to February. Respect to chlorophyll $a$, the data showed that phytoplankton biomass peaks occurred during August and October, and also in February (Fig. 5).

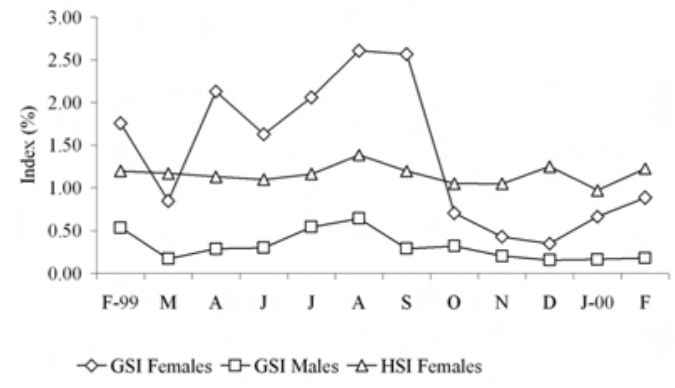

Fig. 4. Seasonal variation of gonadosomatic (GSI) and hepatosomatic (HSI) indexes for females and males of O. niloticus.

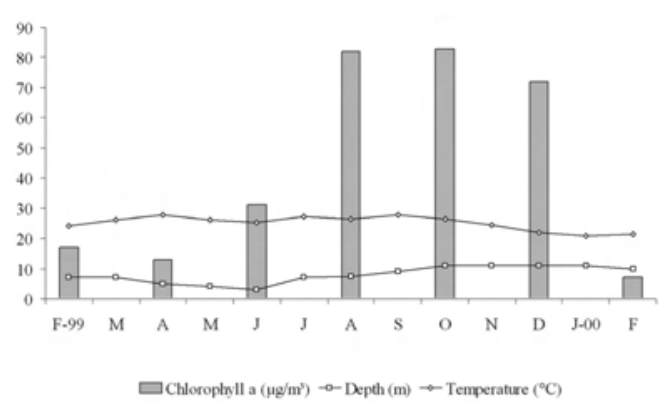

Fig. 5. Seasonal variation of chlorophyll a concentration $\left(\mu \mathrm{g} / \mathrm{m}^{3}\right)$, water temperature $\left({ }^{\circ} \mathrm{C}\right)$ and maximum depth $(\mathrm{m})$ at Emiliano Zapata dam.

\section{DISCUSSION}

Sex ratio for $O$. niloticus in Emiliano Zapata dam indicate that males and females 
are different in numbers and the deviation from the expected 1:1 (male:female) was significant. This is not supported by other studies on the same species in different aquatic systems (Babiker and Ibrahim 1979, Basurto 1984, Gómez-Márquez et al. 2003). However, Ramos-Cruz (1995) mentioned that the sex ratio for $O$. aureus was of 2.6:1 males:females which considers normal. Fawole and Arawomo (2000) also indicated that for every female, there is a male specimen in Sarotherodon galilaeus. Nikolsky (1963) cited that the sex ratio varies considerably from species to species, but in the majority of cases it is close to one, and may vary from year to year in the same population.

Fryer and Iles (1972) points out that in the African lakes it is common in the cichlid populations that males dominate because they generally present more growth than females, without this representing a risky situation for the fishery.

In this study the sex ratio was different in each one of the samples. This variation in the sex ratio can occur because once the fertilization of the eggs has concluded the males possibly emigrate from the areas of spawning toward feeding areas located in the shallow part of the lake (where they are captured). The females possibly go toward submerged vegetation and rocky areas to avoid predators (including fishermen) and to carry out the incubation and protection of the offspring.

In spite of the variation in the gonadal stage of males and females, the periodicity of spawning for $O$. niloticus at Emiliano Zapata dam, indicates that the fish spawn at least twice during the breeding season (August and February). Babiker and Ibrahim (1979) for T. nilotica; Stewart (1988), Castrejón et al. (1995), Admassu (1996) and Gómez-Márquez et al. (2003) for O. niloticus, found that females breed more than once in a season.

Morales (1991) mentioned that the frequency of tilapia spawning varies considerably in function of the environmental factors, and that in Mexico tilapia may present up to 10 spawning events per year.

The observed first time maturation size for Nile tilapia is not exceptional. Similar size at first maturation have been reported by GómezMárquez et al. (1993) for O. mossambicus, Basurto (1984) for T. nilotica, Gómez-Márquez et al. (2003) for O.niloticus and, Fawole and Arawomo (2000) for S. galilaeus. However, the size at first maturation of this species is small compared with other species at different aquatic system (Ramos-Cruz 1995, Palacios 1995, Jiménez 1999). Uchida and King (1962, in Morales 1991) mentioned that the tilapias attain their sexual maturity at three months old with a total length of 8 to $16 \mathrm{~cm}$. de Graff et al. (1999) cited that the first maturation size for reared Nile tilapia is of $30-50 \mathrm{~g}$.

This difference arises because the sexual maturity is a function of the size and may be influenced by the abundance and seasonal availability of food, the temperature, the photoperiod and other environmental factors at different localities (Nikolsky 1963, Babiker and Ibrahim 1979).

Arredondo-Figueroa and Guzmán-Arroyo (1986) mentioned that Oreochromis spp is a mouth brooder with small gonads of less than 700 eggs. In this study, we reported a fecundity range from 243 to 847 eggs. This result is lower than that observed by other workers for O. niloticus. Fryer and Iles (1972) obtained a fecundity of 3706 eggs from a gigantic female specimen with total length of $57 \mathrm{~cm}$ of T. nilotica. The maximum numbers of eggs counted in the ripe ovaries of any mouth-brooding cichlid are 4300 in a specimen of the T. aurea with 25 $\mathrm{cm}$ of total length.

Moyle and Cech (2000) mentioned that in mouthbrooding cichlids, the fecundity is considerably low because the parents assure the survival of the offspring, and in consequence less mortality. In addition, the variation in fecundity may be attributed to differential abundance of food within the members of the population.

Even when expressed in terms of body length, $O$. niloticus fecundity (biometric exponent of 0.88 of length), is much lower than that of most economically exploited species, as mentioned by Babiker and Ibrahim (1979) for T. nilotica, Gómez et al., (1993) for O. mossambicus, Gómez-Márquez et al., (2003) for 
O. niloticus and, Fawole and Arawomo (2000) for S. galilaeus. This is probably a result of the restrictions imposed by the mouth-brooding habit of this species and the limited space available for rearing of the spawn in the mouth cavity (Babiker and Ibrahim 1979).

The occurrence of eggs of varying sizes is also an indication of multiple spawning by this species and the egg diameter varied in fish of the same length or weight. In this study the eggs ranged between 2.1 and $3.7 \mathrm{~mm}$. Similar egg sizes for Nile tilapia were reported by Babiker and Ibrahim (1979), de Graff et al. (1999) and Gómez-Márquez et al. (2003).

In spite of the periodicity of oviposition and spawning, the generation and development of gonads seemed to proceed without interruption as indicated by the high frequency of occurrences of all stages of gonadal maturation. Babiker and Ibrahim (1979) cited that it is possible that in this species as in the majority of teleosts, oogenesis proceeds uninterruptedly or cyclically throughout reproductive life. Mature ovaries were available all the year round and this is an indication that the fish breeds throughout the year. The GSI for the males was always lower than from females. This is associated with relatively heavier female gonads. These observations suggest, that, in spite of the pattern of variation in the mean gonad weight, the evidence found in this study corroborates the summer and winter spawning seasons for this species. Zenebe's (1988, cited in Admassu 1996) data on GSI of the females suggest a slight increase in breeding between July and August.

Most species of tilapia breed continuously, but in some of them, breeding activity increases during periods of intense sunshine and/or rainfall. In this study, a major breeding peak of tilapia is associated with warm temperature, rainfall and rise in water level. The period with high values of GSI for the fish is also the times of increase in phytoplankton biomass (chlorophyll a) at Emiliano Zapata dam. Phytoplankton biomass in this reservoir is shown to increase following high nutrients concentration due to water mixing and rainfall associated changes in the dam hydrology. This increase in phytoplankton biomass may play as one of the environmental cues for an approaching favourable season for offspring better growth and survival, while the other environmental factors may have secondary or indirect effects. A similar conclusion can be drawn also for O. niloticus in Lake Awassa studied by Admassu (1996) and for Sarotherodon (Oerochromis) macrochir of Lake McIlwaine (Marshall, 1979). Nevertheless, a more detailed research is required to investigate the effect of phytoplankton at the time of breeding of $O$. niloticus in the dam.

The liver weight was minimal during summer and spring. Salgado-Ugarte (1995) mentioned that the poor somatic condition during the spawning season is a common observation in many species of fish, and give and indication that the somatic growth is limited due to the development of gonads. Furthermore, the decrease in condition has been ascribed to a depletion of body reserves during gonad maturation.

The data and information presented here indicate that the GSI may perhaps not yield a totally accurate indication of gonadal activity. García-Berthou and Moreno-Amich (1993) cited that the use of the multivariate analysis of covariance (MANCOVA) could be applied most appropriately than the use of this measurement. This method has the advantages of eliminatings the effect of the individual size, the variability increment when comparing variables by means of a ratio and the anomalous characteristics of estimating mean true values of the ratio.

\section{ACKNOWLEDGMENTS}

We thank everyone who kindly assisted in several parts of the work for collecting, processing and providing measurements of $O$. niloticus. The authors acknowledge Benny Weiss Steider for his help with the manuscript. This work was supported by the Facultad de Estudios Superiores Zaragoza, U.N.A.M. and by DGAPA-PAPIME project code 192031 . 


\section{RESUMEN}

Se analizó la biología reproductiva de la tilapia en la presa Emiliano Zapata, Morelos, México. Para esto se realizaron muestreos de febrero 1999 a febrero 2000. Se tomaron 50 organismos mensuales de la captura comercial obtenidos con una atarraya de $6.5 \mathrm{~cm}$ de luz de malla. La proporción sexual fue de1:1.29 hembras:machos $\left(\chi^{2}=10.26 ; p<0.05\right)$. La madurez sexual se alcanza a los $151.3 \mathrm{~mm}$ (hembras) y a los $152.0 \mathrm{~mm}$ (machos) de longitud total. Se detectaron dos épocas de reproducción para la especie: durante la estación lluviosa (agosto) y durante la estación de secas (febrero). La fecundidad relativa presentó mayor correlación con la longitud $(\mathrm{r}=0.7473 ; \mathrm{p}<0.002)$ que con el peso $(r=0.7395 ; \mathrm{p}<0.002)$. Por otra parte, el intervalo para la fecundidad osciló entre 243 y 847 ovocitos por pez, con diámetros de 300 a $3700 \mu \mathrm{m}$. Asimismo, la actividad reproductiva de la especie en Agosto y Febrero, coincide con el incremento de biomasa fitoplanctónica.

Palabras clave: Reproducción, Oreochromis niloticus, índice gonadosomático, índice hepatosomático, fecundidad.

\section{REFERENCES}

Admassu, D. 1996. The breeding season of tilapia, Oreochromis niloticus L. in Lake Awassa (Ethiopian rift valley). Hydrobiologia 337: 77-83.

Anonymous. 2002. Anuario Estadístico de Pesca 2001. Dirección de Estadística y Registro Pesquero. Secretaría de Pesca, México, D.F. 235 pág.

Arias-Rodriguez, L., S. Páramo-Delgadillo \& A. de la Luz Durán-González. 2006. Estudio citogenético en la mojarra pinta Parachromis managuensis (Pisces: Cichlidae). Rev. Biol. Trop. 54(1): in press.

Arredondo-Figueroa, J.L. \& M. Guzmán-Arroyo. 1986. Actual situación taxonómica de las especies de la Tribu Tilappini (Pisces: Cichlidae) introducidas en México. An. Inst. Biol. U.N.A.M., Serie Zool. 56(2): 555-572.

Arredondo-Figueroa, J.L. \& M. Tejeda-Salinas. 1989. El hueso faríngeo, una estructura útil para la identificación de especies de la tribu Tilapiini (Pisces: Cichlidae) introducidas en México. An. Inst. Cienc. del Mar y Limnol. U.N.A.M. 16: 59-68.

Babiker, M.M. \& H. Ibrahim. 1979. Studies on the biology of reproduction in the cichlid Tilapia nilotica (L): Gonadal maduration and fecundity. J. Fish. Biol. 14: 437-447.
Bagenal, T. 1978. Aspects of fish fecundity, p. 75-101. In Shelby, D.G. (eds.). Ecology of freshwater fish production. Blackwell Scientific, Oxford, England.

Bardach, E. J., J.H. Ryther \& W.O. Mclarney. 1986. Acuacultura. Crianza y cultivo de organismos marinos y de agua dulce. AGT, México, D.F.: 288-316.

Basurto, M. 1984. Estudio preliminar al conocimiento biológico y pesquero de la Tilapia nilotica (Linnaeus) en la laguna de Chila, Veracruz. Tesis de Licenciatura. Universidad del Noreste de Tampico, Tampico, México. $50 \mathrm{p}$.

Castrejon, M.T., R. Palacios \& A. García-Alarcón. 1995. Patrón reproductivo de la tilapia del Nilo Oreochromis niloticus, Programa-Resúmenes. XIII Congreso Nacional de Zoología. Nov. 1. Morelia, Michoacán, México. p. 24.

Coward, R. \& N.R. Bromage. 1998. Histological classification of oocyte growth and the dynamics of ovarian recrudescence in Tilapia zillii. J. Fish. Biol. 53: 285-302.

de Graaf, G.J., F. Galemoni \& E.A. Huisman. 1999. Reproductive biology of pond reared Nile tilapia, Oreochromis niloticus L. Aquaculture Res. 30: 25-33.

de Vlaming, V., G. Grossman \& F. Chapman. 1982. On the use the gonosomatic index. Comp. Biochem. Physiol. Vol. 73A, No 1: 31-39.

Fawole, O.O. \& G.A.O. Arawomo. 2000. Fecundity of Sarotherodon galilaeus (Pisces: Cichlidae) in the Opa reservoir, Ile-Ife, Nigeria. Rev. Biol. Trop. 48: 201-204.

Fryer, G. \& T.D. Iles. 1972. The Cichlid Fishes of the Great Lakes of Africa. Their Biology and Evolution. Oliver and Boyd, Edinburgh, Scotland. 641 pág.

García-Berthou, E. \& R. Moreno-Amich. 1993. Multivariate analysis of covariance in morphometric studies of the reproductive cycle. Can. J. Fish. Aquat. Sci. 50: 1394-1399.

Gómez-Márquez, J.L., R.M.A. Castillo, M.J.G. Fabila \& V.A.D. Zamora. 1993. Reproducción de la tilapia en la laguna El Rodeo, Estado de Morelos, México. Tópicos de Investigación y Posgrado III (1): 16-22.

Gómez-Marquez, J.L. 1998. Age and growth of Oreochromis niloticus (Perciformes: Cichlidae) in Mexico. Rev. Biol. Trop. 46: 929-936.

Gómez-Márquez, J.L., B. Peña-Mendoza, I.H. SalgadoUgarte \& M. Guzmán-Arroyo. 2003. Reproductive 
aspects of Oreochromis niloticus (Perciformes: Cichlidae) at Coatetelco lake, Morelos, Mexico. Rev. Biol. Trop. 51: 221-228.

Günther, J. \& R. Jiménez-Montealegre. 2004. Efecto del probiótico Bacillus subtilis sobre el crecimiento y alimentación de tilapia (Oreochromis niloticus) y langostino (Macrobrachium rosenbergii) en laboratorio. Rev. Biol. Trop. 52: 937-943.

Hernández-Avilés, J.S. \& B. Peña-Mendoza. 1992. Rendimientos piscícolas en dos bordos semi-permanentes en el estado de Morelos, México. Hidrobiológica 3/4: 11-23.

Holden, M.J. \& D.F.S. Raitt (Editores). 1975. Manual de ciencia pesquera. Parte 2. Métodos para investigar los recursos y su aplicación. Documento Técnico. FAO. Pesca, Roma (115) Rev. 1: 211 pág.

Jiménez, B.M.L. 1999. Análisis de la pesquería de la tilapia Oreochromis spp. (Pisces:Cichlidae) en la presa Adolfo López Mateos, Michoacán-Guerrero. Tesis de Doctorado en Ciencias, Instituto de Ciencias del Mar y Limnología, UNAM, México, D.F. 341 p

Jiménez, B.L. \& R. Nepita. 2000. Espectro trófico de la tilapia Oreochromis aureus (Perciformes, Cichlidae) en la presa Infiernillo, Mich.-Gro. México. Rev. Biol. Trop. 48: 487-494.

Jiménez-Badillo, L. 2006. Age-growth models for tilapia Oreochromis aureus (Perciformes, Cichlidae) of the Infiernillo reservoir, Mexico and reproductive behaviour. Rev. Biol. Trop. 54(1): in press.

King, M. 1995. Fisheries biology, assessment and management. Blackwell Science, London. 341 p.

Marshall, B.E. 1979. Observations on the breeding biology of Sarotherodon machochir (Boulenger) in Lake McIlwaine, Rhodesia. J. Fish Biol. 14: 419-424.

Morales, D.A. 1991. La Tilapia en México. Biología, Cultivo y Pesquerías. AG, México, D.F. 190 pág.

Morales, B.E. 1992. Evaluación de algunos aspectos biológico-pesqueros de la tilapia Oreochromis aureus (Steindachner, 1864) en la presa Vicente Guerrero,
Las Adjuntas, Tamaulipas. Tesis de Licenciatura, ENEP-Iztacala, UNAM, México, D.F. 28 p.

Moyle, B.P. \& J.J. Cech, Jr. 2000. Fishes: An Introduction to Ichthyology. Prentice Hall, New Jersey, USA: 123-144.

Nikolsky, D.V. 1963. The ecology of fishes. Academic, New York, USA. 352 p.

Palacios, S.S.E. 1995. Estudio biológico pesquero de la tilapia Oreochromis aureus (Steindachner, 1864) en la presa Adolfo López Mateos (El Infiernillo), Michoacán-Guerrero, México. Tesis de Licenciatura, Facultad de Ciencias, UNAM, México, D.F. 81 p.

Peña, B. \& R. Domínguez. 1999. The effects of different photoperiods on body growth, gonadal growth and hypotalamic monoamine content in juvenil Oreochromis niloticus Linnaeus, 1757. Hidrobiológica 9(1): 63-70

Ramos-Cruz, S. 1995. Reproducción y crecimiento de la mojarra tilapia (Oreochromis aureus) en la Presa Benito Juárez, Oaxaca, México, en 1993. INPSEMARNAP. México. Ciencia Pesquera No. 11 (Nueva época): 54-61.

Salgado-Ugarte, I.H. 1995. Nonparametric methods for fisheries data analysis and their application in conjunction with other statistical techniques to study biological data of the Japanese sea bass Lateolabrax japonicus in Tokyo Bay. Ph. D. in Aquatic Bioscience Thesis, Laboratory of Fisheries Biology, University of Tokyo, Japan. 389 p.

Shoesmith, E. 1990. A comparison of methods for estimating mean fecundity. J. Fish. Biol. 36: 29-37.

Stewart, K.M. 1988. Changes in condition and maturation of the Oreochromis niloticus L. population of Ferguson's Gulf, Lake Turkana, Kenya. J. Fish. Biol. 33: 181-188.

Wetzel, R.G. \& G.E. Likens 1979. Limnological analyses. W.B. Saunders, Philadelphia, Pennsylvannia, USA 357 p.

Yi, Y, C.K. Lin \& J.S. Diana. 1996. Influence of Nile tilapia (Oreochromis niloticus) stocking density on their growth and yield in cages and ponds containing the cages. Aquaculture 146: 205-215. 